\title{
The Immunopathology of COVID-19 and the Cannabis Paradigm
}

\author{
Nicole Paland ${ }^{1}$, Antonina Pechkovsky ${ }^{1}$, Miran Aswad ${ }^{1}$, Haya Hamza ${ }^{1}$, Tania Popov ${ }^{1}$, \\ Eduardo Shahar ${ }^{2}$ and Igal Louria-Hayon ${ }^{1,3,4 *}$
}

${ }^{1}$ Medical Cannabis Research and Innovation Center, Rambam Health Care Campus, Haifa, Israel, ${ }^{2}$ Clinical Immunology Unit, Rambam Health Care Campus, Haifa, Israel, ${ }^{3}$ Clinical Research Institute at Rambam (CRIR), Rambam Health Care Campus, Haifa, Israel, ${ }^{4}$ Department of Hematology, Rambam Health Care Campus, Haifa, Israel

Coronavirus disease-19 caused by the novel RNA betacoronavirus SARS-CoV2 has first emerged in Wuhan, China in December 2019, and since then developed into a worldwide pandemic with $>99$ million people afflicted and $>2.1$ million fatal outcomes as of 24th January 2021. SARS-CoV2 targets the lower respiratory tract system leading to pneumonia with fever, cough, and dyspnea. Most patients develop only mild symptoms. However, a certain percentage develop severe symptoms with dyspnea, hypoxia, and lung involvement which can further progress to a critical stage where respiratory support due to respiratory failure is required. Most of the COVID-19 symptoms

OPEN ACCESS

Edited by:

Amiram Ariel,

University of Haifa, Israel

Reviewed by:

Kuldeep Dhama,

Indian Veterinary Research Institute

(IVRI), India

Abhilash Perisetti,

University of Arkansas for Medical

Sciences, United States

*Correspondence:

Igal Louria-Hayon

i_louriahayon@rambam.health.gov.il

Specialty section:

This article was submitted to Inflammation,

a section of the journal

Frontiers in Immunology

Received: 19 November 2020 Accepted: 26 January 2021

Published: 12 February 2021

Citation:

Paland N, Pechkovsky A, Aswad M,

Hamza H, Popov T, Shahar E and Louria-Hayon I (2021) The

Immunopathology of COVID-19 and the Cannabis Paradigm.

Front. Immunol. 12:631233.

doi: 10.3389/fimmu.2021.631233 are related to hyperinflammation as seen in cytokine release syndrome and it is believed that fatalities are due to a COVID-19 related cytokine storm. Treatments with anti-inflammatory or anti-viral drugs are still in clinical trials or could not reduce mortality. This makes it necessary to develop novel anti-inflammatory therapies. Recently, the therapeutic potential of phytocannabinoids, the unique active compounds of the cannabis plant, has been discovered in the area of immunology. Phytocannabinoids are a group of terpenophenolic compounds which biological functions are conveyed by their interactions with the endocannabinoid system in humans. Here, we explore the anti-inflammatory function of cannabinoids in relation to inflammatory events that happen during severe COVID-19 disease, and how cannabinoids might help to prevent the progression from mild to severe disease.

Keywords: SARS-CoV2, COVID-19, cytokine release syndrome, cytokine storm, inflammation, cannabis, cannabinoids, cannabinoid receptors

\section{INTRODUCTION}

Coronavirus disease 19 (COVID-19) caused by the novel severe acute respiratory syndromecoronavirus 2 (SARS-CoV2) firstly emerged in December 2019 in Wuhan in China and has, since then, evolved into a global pandemic (1). It is a novel enveloped RNA betacoronavirus, which binds with its spike surface protein (S-protein) to angiotensin-converting enzyme 2 (ACE2) on the cellular host's surface. Entry of the virus to the host cell by endocytosis requires cleavage of the S-protein by the host cell transmembrane protease serine-2 (TMPRSS-2) (2). ACE2 is expressed in a diverse array of cells including cells of the upper respiratory, central nervous and vasculature system as well as of the eye, lung, liver, heart, kidney, and intestine contributing to the diverse clinical pulmonary and extra-pulmonary manifestations of COVID-19 including gastrointestinal involvement of COVID-19 [(3-5); Figure 1]. 


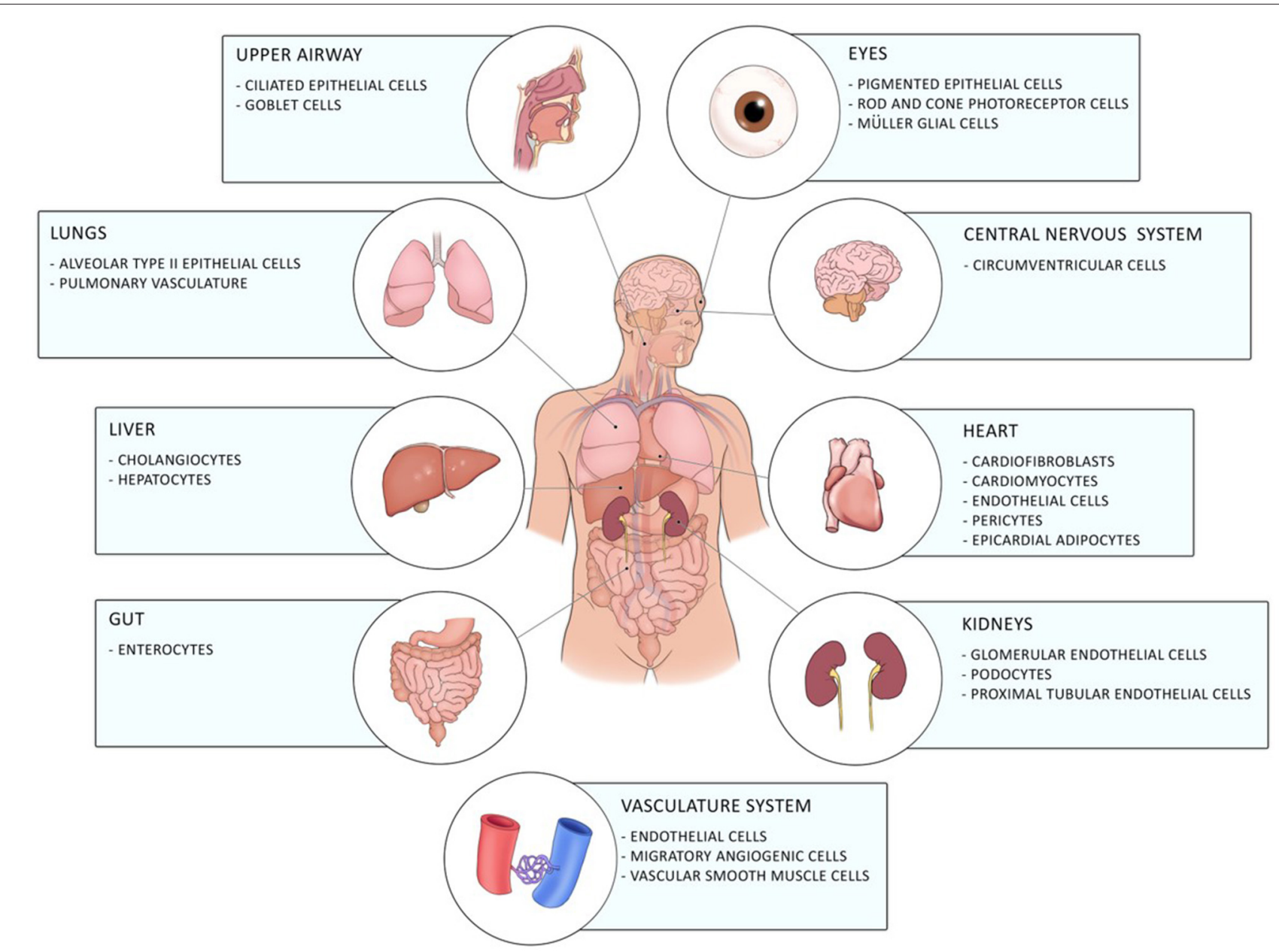

FIGURE 1 | Distribution of ACE2 in the human body. ACE2 is expressed in different cells of the eye, the upper airway, the lung, the liver, the gut, the central nervous system, the heart, the vasculature system, and of the kidneys.

SARS-CoV2 similarly to other coronavirus outbreaks SARSCoV1 and Middle East Respiratory Syndrome (MERS) targets the lower respiratory tract system leading to pneumonia with fever, cough, and dyspnea (6). Most patients (80\%) show only mild disease (either no or mild pneumonia), a smaller proportion (14\%) develops severe symptoms with $>50 \%$ pulmonary manifestations as observed on imaging tests including dyspnea and hypoxia. A small proportion (5\%) develop a critical disease with respiratory failure, multi-organ failure or systemic shock. About $10-30 \%$ of hospitalized patients get into a critical stage where they require intensive care for respiratory support. Approximately $1 \%$ of all patients have a fatal outcome $(7,8)$. Patients who developed acute respiratory distress syndrome (ARDS) and required mechanical ventilation had a reported mortality rate of $88.1 \%$ in the New York City area in March 2020 (9). Interestingly, not only elderly, but also young patients with only mild comorbidities like hypertension, diabetes mellitus and obesity developed respiratory failure (10).
Epidemiological data show that differences in susceptibility and severity of COVID-19 widely depend on biological and socio-economic factors. A lower incidence of severe disease was observed in females with caucasian heritage $(11,12)$. This might be due to the fact that females are less susceptible to viral infections due to a higher macrophage and neutrophil activity and an increased antibody production and lower cytokine production (12). On the other hand seem ethnic minorities more susceptible to contract a SARS-CoV2 infection $(11,12)$. Ethnic minorities usually have less access to a functioning health care system, higher levels of medical comorbidities, and their lower socioeconomic status contributes to a weak cell-mediated immunity $(11,12)$.

Development of a severe disease progresses in two steps; mild symptoms at the start are followed by respiratory worsening after $\sim 10$ days after onset of initial symptoms. This deterioration is accompanied with clinical presentations of ground-glass lung opacities on chest imaging, lymphocytopenia, high D-dimer, and high prothrombin (1). In patients with 
moderate disease, a progressive reduction in inflammatory responses happens in convalescence while in patients with severe disease, these levels remain high and an additional cluster of inflammation appears (13) possibly due to a defective type I interferon response [(14); Figure 2]. Those systemic hyperinflammatory patterns in COVID-19 patients are similar to those in cytokine release syndrome (CRS) and the occurrence of CRS in severe disease was suggested (15).

Although certain patterns for the susceptibility to develop severe COVID-19 are recognizable $(13,16)$, the inflammatory response and the immune dynamics of the infected patient are still not fully understood. This makes the exact course of a SARS-CoV2 infection and the correlation to a certain clinical manifestation highly unpredictable. Effective and specific anti-viral drugs against SARS-CoV2 are not yet available. The usage of available repurposed anti-inflammatory medicines (17) and antibody-based immunotherapeutics targeting viral clearance $(18,19)$ is still experimental and applied only for the treatment of severely and critically ill patients (20-22). Safe and efficient treatment options that have the potential to halt disease progression at an early stage are needed. Cannabis and cannabinoids with their well-known anti-inflammatory properties may hold this potential.

Cannabis comprises various strains termed Cannabis sativa, Cannabis ruderalis, and Cannabis indica. It is not sure if they are three different species or whether ruderalis and indica are subspecies of $C$. sativa. During the history of the mankind, the cannabis plant was grown for varied uses as for production of fabric, for food, for recreational purposes and for medicinal use. Medically useful substances are produced in the trichomes that sit on the leaves and buds of the plant (23).

The cannabis plant contains more than 550 different components, of which are about 150 belongs to C21 or C22 terpenophenolic phitochemicals, which are predominantly expressed in the cannabis plant thus termed cannabinoids. The other 400 components are terpenes and phenolic compounds (24). The cannabinoids components contains both psychoactive [as 9-tetrahydrocannabinolic acid (THCA)] and non-psychoactive [as cannabidiolic acid (CBDA)] substances (24). The biological properties of the cannabinoids rely on their interaction with the endocannabinoid system includes Gproteins coupled receptors and Transient receptor potential chanels (TRP) (25).

Most interestingly, the anti-inflammatory properties especially of the non-psychoactive cannabidiol were recently explored as anti-viral agents. These effects were shown for the treatment of HIV (26), viral hepatitis $(27)$, or influenza $(28,29)$ as well as orthopoxvirus, borna disease virus or vaccinia virus (30).

Here, we will explore the anti-inflammatory qualities of phytocannabinoids and discuss the possibility of applying cannabinoids as a treatment option for COVID-19 patients. We will explore the recent literature and emphasize the antiinflammatory properties in relation to the events occurring during cytokine release syndrome (CRS) in mild or severe COVID-19 disease.

\section{CYTOKINE RELEASE SYNDROME IN COVID-19 PATIENTS}

Each infection with SARS-CoV2 is closely related to excessive inflammatory events with monocytes/macrophages and $\mathrm{T}$ cells playing a special role (31). Diffuse alveolar damage, pulmonary thrombi and vasculitis occurring predominantly in monocytes and myeloid tissue and an excess of plasma cells in lymph nodes, spleen, and lung was observed $(15,32)$. This leads to a severe increase in white blood cells with concomitant decrease in $\mathrm{CD} 4^{+}$ and $\mathrm{CD}^{+}$lymphocytes resulting in an impaired neutrophil to lymphocyte ratio (33). Inflammatory cells infiltrate the sites of infection at an early stage of the infection with SARS-CoV2 and cause a stormy release of pro-inflammatory cytokines like IL-6, IL-17A, TNF $\alpha$, IFN $\gamma$, IL- $1 \alpha / \beta$, and chemokines like CCchemokine ligand 2 (CCL2) as well as CXC-chemokine ligand 10 (CXCL10) (13). The release of IL-6 by circulating monocytes into the bloodstream leads to an increased activation of $\mathrm{T}$ cells with a concomitant reduced total number of T cells. Monocyte-derived $\mathrm{FNC1}+$ macrophages were found in bronchoalveolar lavage fluid (BALF) $(13,34)$ probably contribute to the hyperinflammation phenomenon (35). CRS can develop at every stage of infection beginning with the entry of the virus into the host causing innate and adaptive immune responses.

\section{Induction of CRS During SARS-CoV2-ACE2 Interaction}

Binding of the virus to ACE2 leads to the internalization of ACE2 and activation of angiotensin II resulting in the activation of nuclear factor kappa B (NF-кB). Subsequently, cytokines IL$6, \mathrm{TNF} \alpha, \mathrm{IL}-1 \beta$, and IL-10 will be produced which might lead to local lung dysfunction including a rise in blood pressure, which contributes to lung injury and deterioration of pulmonary function as occurs in $\operatorname{ARDS}(36,37)$.

\section{Induction of CRS by Innate Immune Cells}

ACE2 was found on $\mathrm{CD} 169^{+}$macrophages in lymph nodes and spleen of COVID-19 patients and severe lymphocyte apoptosis was observed probably induced by viral antigens through Fas upregulation (38). CD169+ cells control viral replication via type I interferon, and expose viral antigens to recognition by adaptive immune cells (39). Infection of $\mathrm{CD} 169^{+}$macrophages enables the translocation of the virus to the spleen and lymph nodes, which contributes to the body-wide distribution of the virus resulting in accumulation of pro-inflammatory monocytes and macrophages at the sites of infection and at sites adjacent to the infection (40).

Monocyte derived FCN1+ macrophages that produce proinflammatory cytokines and chemokines were found in the BALF of patients with ARDS (34). This might contribute to the induction of $\mathrm{T}$ cell apoptosis, which might lead to pneumonia and disease progression to ARDS (41). Moreover, production of IL-6 in the spleen and lymph nodes, and of IL-6, TNF $\alpha$, IL-10, and PD-1 by alveolar macrophages induces lymphocyte necrosis, further contributing to the development of lymphocytopenia and cytokine storm in the lung (38).

Monocytes and mononuclear cells in the peripheral blood and BALF are activated and secrete IL-6, IL-10, and TNF $\alpha$, 


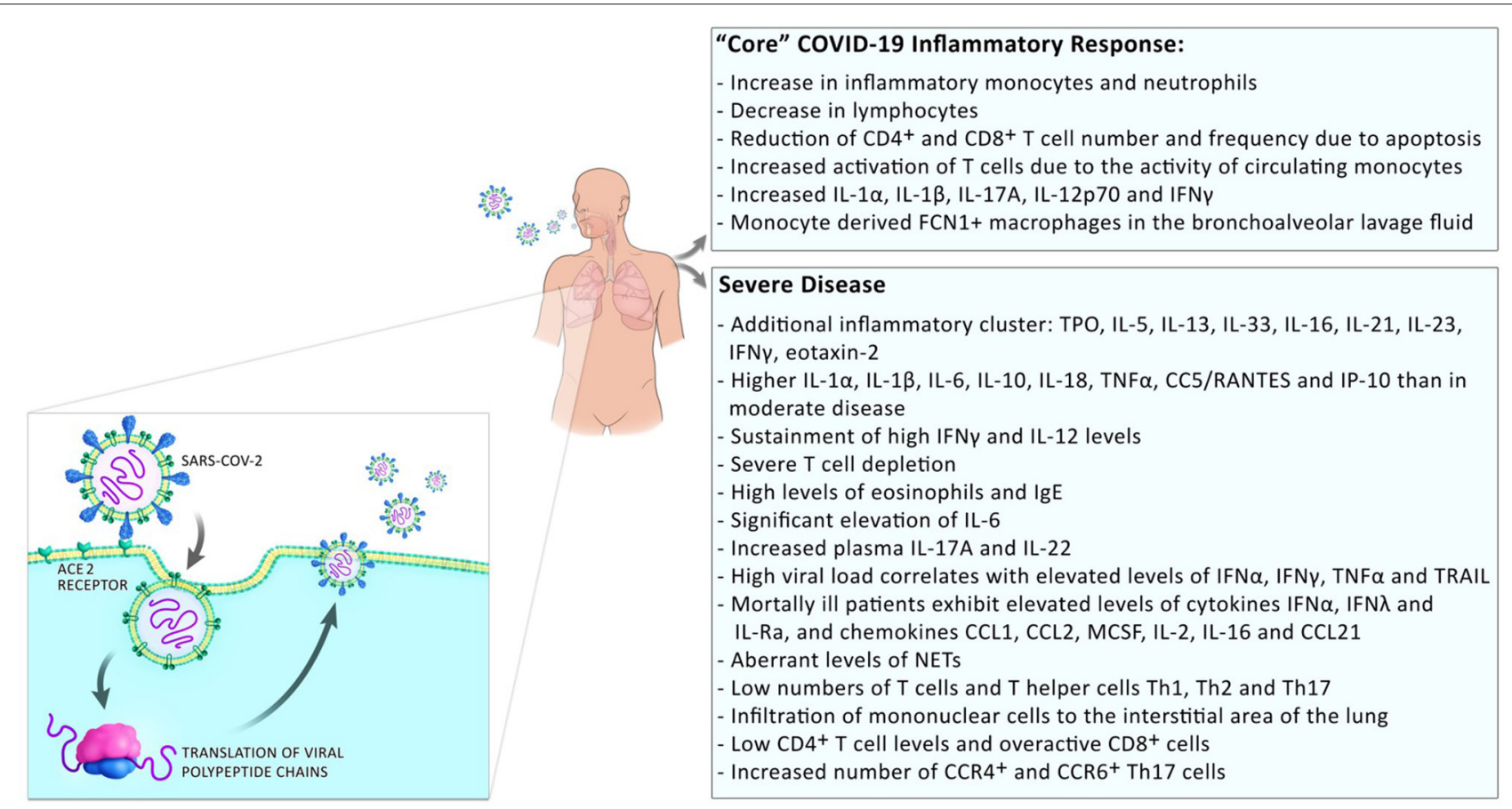

FIGURE 2 | Inflammatory responses in COVID-19 patients. Inflammatory responses to SARS-CoV2 comprise a "core" inflammatory response, which all COVID-19 patients experience. In patients with mild disease, the inflammatory response resolves on the way to convalescence. The appearance of additional inflammatory clusters is observed during progression to severe disease. This includes the release of a higher number of systemic pro-inflammatory cytokines, low numbers but over-reactive T cells, and infiltration of monocytes/macrophages to the sites of infection.

and chemoattractors of macrophages' IFN-induced protein 10 (IP-10), and MCP-1 (42). In peripheral blood mononuclear cells (PBMC) and BALF, high levels of neutrophil-attracting chemokines CXCL2 and CXCL8 attract neutrophils to the site of inflammation (43). Neutrophils secrete extracellular webs of DNA and histone to infectious particles, termed NETs, which are found aberrantly in patients with ARDS (44). They are believed to contribute to venous and arterial thrombosis in critical disease, multi-organ, and respiratory failure as well as coagulopathy due to their impact on the regulation of cytokine release (42).

\section{Induction of CRS by Adaptive Immune Cells}

Lymphocytopenia is a well-observed symptom in patients with severe COVID-19. It comprises a highly reduced number of circulating $\mathrm{B}$ and $\mathrm{T}$ cells combined with an increase in neutrophils and hyperactivation of monocytes and macrophages.

Patients with severe disease symptoms have low $\mathrm{T}$ cells and T helper cells, Th1, Th2, and Th17 numbers (45), either due to $\mathrm{T}$ cell apoptosis by high amounts of cytokines secreted by $\mathrm{CD}^{+} \mathrm{T}$ cells $(46,47)$ or due to the redistribution to other tissues resulting in the infiltration of mononuclear cells into the interstitial area of the lung contributing to the development of interstitial pneumonitis (48).

In patients with $\mathrm{ARDS}, \mathrm{CD}^{+}$, and $\mathrm{CD} 8^{+} \mathrm{T}$ cells were found in the peripheral blood 14 days after disease onset. While $\mathrm{CD}^{+}$
$\mathrm{T}$ cells secrete primarily IFN $\gamma, \mathrm{CD} 4^{+} \mathrm{T}$ cells secrete cytokines related to Th1 (IFN $\gamma$, TNF $\alpha$, IL-2) and Th2 (IL-5, IL-9, IL-10) at normal levels (49) albeit at reduced levels in severe COVID-19 (50). Patients with ARDS had low but over-activated $\mathrm{CD}^{+}$cells (51) leading to $\mathrm{T}$ cell exhaustion rendering the $\mathrm{T}$ cell response ineffective (50). In addition, activated T cells, including Th1 and Th17 helper cells, further stimulate the activation of monocytes enabling secretion of IL-1 $\beta$, IL- 6 , and colony stimulating factor (CSF1 and CSF2) to contribute to the worsening of the cytokine storm resulting in organ failure (46).

Another important subset of $\mathrm{T}$ cells comprises regulatory $\mathrm{T}$ cells (Tregs). They are responsible for regulating the immune response to prevent hyperinflammation. To do so, they expand rapidly in antiviral immune responses (52). Inconsistent results have so far been obtained about the levels of Tregs in patients with severe COVID-19. Some observed higher levels of Tregs, while others reported reduced or unchanged levels (45).

As a result of the above, a significant elevation of a plethora of pro-inflammatory cytokine levels was reported. The most prominent elevated pro-inflammatory cytokine is IL-6 in patients with severe symptoms. This IL- 6 production from $\mathrm{CD}_{14}{ }^{+}$and $\mathrm{CD}^{+} 6^{+}$monocytes is driven by GM-CSF produced by Th1 cells (53) directly correlated with virus load (54). Moreover, IL-6 might influence lung-centric coagulopathy by inducing coagulation cascades (55).

Increased numbers of $\mathrm{CCR}^{+}{ }^{+}$and $\mathrm{CCR} 6^{+}$Th17 cells were measured in COVID-19 patients with ARDS (56). Other 
cytokines IL-1, IL-17, TNF $\alpha$, and GM-CSF were associated with Th17 immune responses (57). These observations might explain the occurrence of a Th17-type cytokine storm, and the onset of multiple organ damage in patients with severe COVID-19 (56). Similarly, production of IP-10, CCL5/RANTES ${ }^{4}$, CRP, and Cdimer were higher in patients with severe COVID-19 compared to mild COVID-19 (57). An increase of anti-inflammatory cytokines IL-10 and IL- 4 hints to an elevated Th2 response, which might be involved in the development of pulmonary interstitial fibrosis $(13,58)$. Underlying bacterial infections might contribute to the development of CRS by exacerbating the inflammatory response (59).

\section{TREATMENT OPTIONS FOR COVID-19 PATIENTS}

No specific anti-viral drug for the successful treatment of COVID-19 is available. Several anti-inflammatory drugs are tested in pre-clinical and clinical trials as repurposed drugs for resolving CRS in patients with severe disease including steroids and corticosteroids like dexamethasone (60, 61), monoand polyclonal antibodies normally used in rheumatology, i.e., the IL-6 inhibitor tocilizumab (62-65) including the "famous" monoclonal antibody cocktail REGN-COV2 (66), anti-viral drugs like remdesivir (67) or the HIV-drug combination lopinavir-ritonavir, the anti-parasitic drug hydroxychloroquine (68) as well as drugs against gastrointestinal diseases like famotidine (histamine-2 receptor antagonist), which showed antiviral properties for HIV or omeprazole (proton pump inhibitor) (69) in addition, the administration of convalescent plasma was tested (22).

Most of the drugs with the exception of remdesivir that was recently approved by the FDA, are still in clinical trials or could not reduce mortality (20-22). To prevent mortality, therapies halting disease progression at earlier stages are required. Cannabinoids with their anti-inflammatory function represent potential candidates to avoid CRS (70-72).

\section{CANNABIS AND THE ENDOCANNABINOID SYSTEM}

The cannabis plant comprises $>550$ different chemical constituents, $\approx 150$ of these are cannabinoids and $>400$ noncannabinoids. The main pharmacologically active compounds are the psychoactive tetrahydrocannabinols (THC), $\Delta^{8}$-THC and $\Delta^{9}$-THC, and other non-psychoactive cannabinoids like cannabinol (CBN), cannabidiol (CBD), or cannabigerol (CBG) to name only a few. $\mathrm{CBN}$ was the first cannabinoid that was isolated in 1899 (73). Non-cannabinoids are flavonoids, terpenes, and fatty acids $[(23,24)$; Figure 3$]$.

\section{Cannabinoid Receptors and Their Ligands}

Cannabinoids convey their functions via cannabinoid receptors that are anchored in the cell membrane. Cannabinoid receptors bind to endo- (eCBs) and phytocannabinoids alike comprising the endocannabinoid system. The most studied

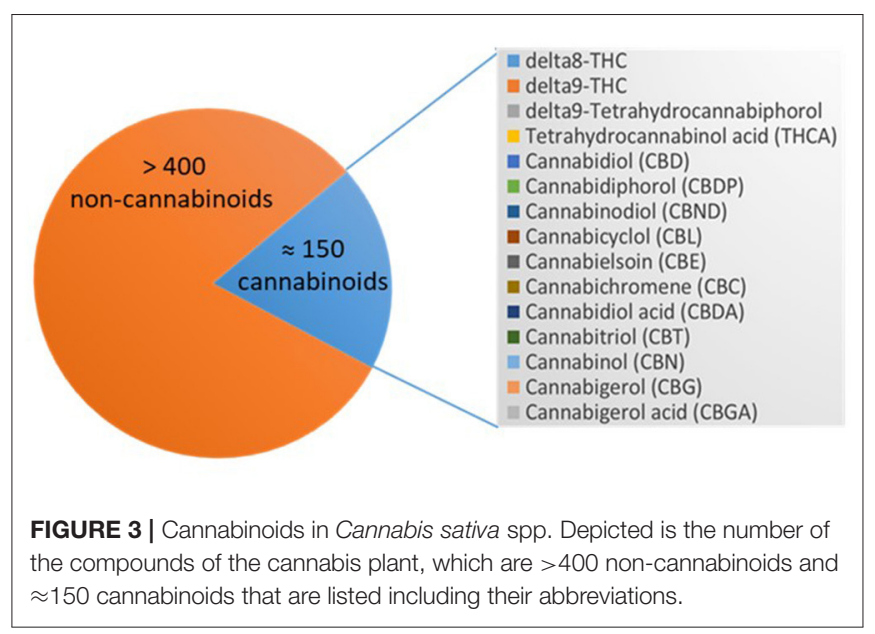

endocannabinoids are 2-arachidonoylglycerol (2-AG) (74) and $\mathrm{N}$-arachidonoylethanolamide (anandamide, AEA) (75). They belong to a group of lipid mediators that are either synthesized and released from membrane phospholipids "on demand" in response to physiological or pathological stimuli by many cell types in the brain or peripheral tissue or may be stored in organelles that might serve as potential platforms for trafficking and accumulation (76).

$2-A G$ is a monoacylglycerol that serves as an intermediate in lipid metabolism (77). It is synthesized when needed by two major pathways, a signaling and a metabolic pathway. The signaling pathway starts from phosphatidylinositol-4,5biphosphate $\left(\mathrm{PIP}_{2}\right)$ and the metabolic pathway starts from triglycerides that contain 2-arachidonate (78). Two second messengers are synthesized from $\mathrm{PIP}_{2}$ : diacylglycerol (DAG) and inositol-1,4,5-triphosphate (75). Triglycerides are hydrolyzed by hormone-sensitive lipase, other lipases, and carboxylesterase to diglycerides that contain 2-arachidonylglycerol (75). Diglycerides are then further processed by two isoforms of diacylglycerol lipase $\alpha$ and $\beta$ (DAGL- $\alpha$ and $-\beta$ ) generating $2-A G$ and a fatty acid (79). Degradation of 2-AG is accomplished by the hydrolysis of the ester bond into arachidonic acid and glycerol by the enzyme monoacylglycerol lipase (MAGL) or $\alpha, \beta$-hydrolase domaincontaining proteins 12 and 6 (ABHD12 and ABHD6) (80).

The biosynthesis of AEA involves two steps: (i) the formation of $\mathrm{N}$-arachidonoyl-phosphatidylethanolamine from phosphatidylethanolamine catalyzed by the calciumdependent $\mathrm{N}$-acyltransferase followed by (ii) the conversion of $\mathrm{N}$-arachidonoylphosphatidylethanolamine to AEA or other $\mathrm{N}$-acylethanolamines through five different metabolic pathways of which the most studied pathway involves $\mathrm{N}$ acyl-phosphatidylethanolamine-hydrolyzing phospholipase D $(76,81)$. Degradation of AEA occurs through cleavage into arachidonic acid and ethanolamine by fatty acid amide hydrolase (FAAH) or N-acylethanolamine-hydrolyzing acid amidase (82).

Both, 2-AG and AEA, can be degraded by cyclooxygenase (COX), lipoxygenase (LOX), or cytochrome $\mathrm{P} 450$ resulting in the formation of oxidized compounds such as hydroxylanandamides and hydroxyeicosatetraenloyl-glycerol or 
prostaglandin-ethanolamines and prostaglandin-glyceryl esters; all of them with different biological functions (76).

Two different classes of receptors are assigned as putative cannabinoid receptors, G-protein-coupled receptors (GPCRs) and transient receptor potential channels (TRP), which we present in further detail in the following two sections and in Table 1.

\section{G Protein-Coupled Receptors}

$\mathrm{G}$ protein-coupled receptors are a family of membrane proteins. They are characterized by seven membrane-spanning $\alpha$-helical domains that are separated by alternating intra- and extracellular loops. GPCRs mediate the cellular response to neurotransmitters and hormones and are mostly responsible for taste, vision, and olfaction. The most prominent GPCRs that mediate endo- and phytocannabinoid signaling believed to be involved in signal transduction of the immune system are CB1R, CB2R, GPCR18, and GPCR55 (121).

\section{Transient Receptor Potential Channels}

Transient receptor potential (TRP) channels are a family of ion channels. They are membrane proteins which consist of channel subunits built of six putative transmembrane-spanning segments (S1-S6) with a pore-forming loop between S5 and S6 which assemble into tetramers to form functional channels (122). TRPs are involved in the signal transduction of numerous chemical and physical stimuli and regulate many neural signaling processes and other physiological functions such as temperature sensation, smell, taste, vision, pressure, or pain perception (123). Thus, they are potentially attractive targets for the therapeutic use of phytocannabinoids in the treatment of sensory, inflammatory or dermatological pathologies (124). Most TRPs can cause channelopathies which are risk factors for many disease states (125).

TRPs that are putative cannabinoid receptors are TRPV1-4, TRPA1, and TRPM8 (126).

\section{Anti-inflammatory Properties of Cannabinoids and Their Potential to Downregulate COVID-19 Related CRS}

First indications that cannabis has the potential to influence the disease course of COVID-19 were already published 3 years before the outbreak of the current pandemic. Researchers from Italy examined the potential of a hemp seed protein isolate that was prepared from defatted hemp seed by alkaline solubilization/acid precipitation as inhibitors for ACE-2. Four potentially bioactive peptides GVLY, IEE, LGV, and RVR were identified in the tested fraction by mono- and bidimensional NMR and LC-MS analyses. All four peptides had ACE-inhibitory activity rendering hemp seeds a potential agent to inhibit entry of SARS-CoV2 into the cells (127).

Recently, Canadian researchers have tested CBD extracts of 800 different C. sativa lines on $3 \mathrm{D}$ human models of oral, airways, and intestinal tissues and found 13 low THC/high CBD lines that modulated ACE2 and TMPRSS2 levels, which might lower the virus load (128). ACE2-reducing activity of cannabisderived products were confirmed by a different group. They extracted a CBD, CBG, and THCV-containing fraction of a $C$. sativa strain and tested it in vitro in comparison to a standard phytocannabinoid agent. Both products reduced the secretion of pro-inflammatory cytokines IL-6, IL-8, CCL2, and CCL7 from the alveolar epithelial cell line A549, induced polarization of the macrophage cell line KG1 and increased the phagocytosis. CD36 and type II receptor for the Fc region of IgG (Fc $\gamma$ RII) were upregulated. The researchers reported a certain superiority of the standard phytocannabinoids compared to the cannabisderived fraction but cannot give recommendations for usage of cannabis in the treatment of COVID-19 (129). Another recent study simulated viral infections using the synthetic RNA Poly I:C and could show that Poly I:C-induced ARDS could be prevented by CBD (130) through the upregulation of apelin, a peptide regulating central and peripheral immunity that was severely downregulated in a murine model of ARDS (131). In the following two sections we will present the processes of regulation of the immune responses of endo- and phytocannabinoids.

\section{Regulation of Immune Responses by Endocannabinoids via $\mathrm{CB} 1$ and $\mathrm{CB} 2$}

The endocannabinoid system has anti-inflammatory activities in innate and adaptive immunity. It regulates migration and trafficking of different immune cells dependent on its receptors. Experiments with human bone marrow cells obtained by aspiration from healthy donors showed that the migration of human hematopoietic stem and progenitor cells was modulated by endocannabinoids. Endocannabinoids receptors $\mathrm{CB} 1$ and CB2 were expressed by bone marrow derived hematopoietic stem cells and $\mathrm{CD} 34^{+}$cells. AEA and $2-\mathrm{AG}$ were detected in the microenvironment of peripheral blood and bone marrow, which were secreted by bone marrow mesenchymal stem cells. Migration of hematopoietic stem cells was stimulated by AEA and $2-A G$ and blocked by $\mathrm{CB}$ receptor antagonists rendering endocannabinoids putative candidates for the enhancement of the migration of hematopoietic stem cells (132).

Cell trafficking of mature immune and effector cells, like lymphocytes, macrophages, neutrophils, and dendritic cells can be regulated by endocannabinoids [rev. in (133)]. It was reported that exogenously added 2-AG leads to the attenuation of lymphocyte proliferation through the decrease of Th1- and Th17-associated cytokines IL-6, IL-2, and TNF $\alpha$. Moreover, activated $B$ and $T$ cells that produce high levels of 2-AG inhibit in a feedback loop $\mathrm{T}$ cell activation and proliferation, making exogenously applied 2-AG a putative candidate for therapeutic usage in Th1- or TH17-dependent diseases (134). Upon antigen activation by pathogens, macrophages, and dendritic cells produce and release $2-A G$, which results in the upregulation of 2-AG levels in the serum and lymph nodes of mice during vaccination $\mathrm{CB} 2$ dependently. In a murine immunization model, transient administration of $\mathrm{CB} 2$ antagonist AM630 or inverse antagonist JTE907 increased the intensity of antigen-specific immune responses by upregulation of immunomodulatory genes in secondary lymphoid tissue (135). AEA inhibited macrophage-mediated killing of the TNF $\alpha$ sensitive mouse alveolar macrophage cell line L929 (136). Correa 
TABLE 1 | Cannabinoids receptors.

\begin{tabular}{|c|c|c|c|}
\hline Receptor & Location in immune cells/tissue & Function in immunity & Ligands \\
\hline CB1 and CB2 & $\begin{array}{l}\text { - Immune tissue (spleen and thymus) and } \\
\text { leukocyte subpopulations like natural killer } \\
\text { cells, B-cells, and peripheral blood } \\
\text { mononuclear cells }(83,84)\end{array}$ & $\begin{array}{l}\text { - Reduces IL-2 synthesis (85) } \\
\text { - Suppression of T cell activation (86-89) } \\
\text { - Inhibition of lymphocyte proliferation and } \\
\text { IL-17 secretion (86) } \\
\text { - Regulation of function of intestinal neutrophils } \\
\text { (90) } \\
\text { - Regulation of acute trafficking of neutrophils } \\
\text { to site of inflammation (91) } \\
\text { - Retention of immature B cells in the bone } \\
\text { marrow (92) } \\
\text { - Immunosuppression in B cells after AEA or } \\
\Delta^{9} \text {-THC ligand binding (93) }\end{array}$ & $\begin{array}{l}\text { Endocannabinoids: } \\
\text { - 2-AG (94), AEA (95) } \\
\text { Phytocannabinoids: } \\
-\Delta^{9}-\mathrm{THC} \text { and } \Delta^{8} \text {-THC as partial agonists } \\
\text { regulating pain management }(96,97) \\
\text { - CBN as agonist (98) } \\
\text { - CBD as a weak antagonist (99), as a negative } \\
\text { allosteric modulator (100), and as an inhibitor } \\
\text { of anandamide uptake (101) } \\
\text { - CBG as a weak partial agonist (102, 103), and } \\
\text { as an inhibitor of AEA uptake (101) } \\
\text { - CBC as weak agonist (103), and as an inhibitor } \\
\text { of AEA uptake (101) } \\
\text { - } \Delta^{9}-\mathrm{THCV} \text { as an antagonist (104) }\end{array}$ \\
\hline GPR55 & - Leukocytes & $\begin{array}{l}\text { - T cell migration (109) } \\
\text { - Hyperalgesia associated with inflammatory } \\
\text { and neuropathic pain (110) }\end{array}$ & $\begin{array}{l}\text { Endocannabinoids: } \\
\text { - AEA, 2-AG, and virodhamine (111) } \\
\text { Phytocannabinoids: } \\
-\Delta^{9}-\mathrm{THC} \text { as an agonist (112) and LPI inhibitor } \\
\text { (113) } \\
\text { - CBD as antagonist (111) } \\
\text { - CBG as weak LPI inhibitor (113) } \\
-\Delta^{9}-\mathrm{THCV} \text { as a partial agonist and LPI inhibitor } \\
\text { (113) } \\
\text { - CBDV as a LPI inhibitor (113) }\end{array}$ \\
\hline TRPV2 & $\begin{array}{l}\text { - Human and mouse B cells } \\
\text { - Human dendritic cells and neutrophils } \\
\text { - Mouse monocytes and macrophages }\end{array}$ & $\begin{array}{l}\text { - Translocation of TRPV2 to the plasma } \\
\text { membrane plays a role in the chemotaxis of } \\
\text { macrophages and in phagocytosis (114) } \\
\text { - Some analgesic and anti-proliferative } \\
\text { properties of CBD may be mediated by } \\
\text { TRPV2 activation (115) }\end{array}$ & $\begin{array}{l}\text { Phytocannabinoids: } \\
-\Delta^{9} \text {-THC, CBD, CBG, } \Delta^{9}-\mathrm{THCV} \text {, and CBDV } \\
\text { as agonists }(101,116)\end{array}$ \\
\hline
\end{tabular}

CB, cannabinoid receptor; 2-AG, 2-arachidonoylglycerol; AEA, N-arachidonoylethanolamide; NADA, N-arachidonoyl dopamine; THC, tetrahydrocannabinols; CBN, cannabinol; CBD, cannabidiol; CBG, cannabigerol; CBC, cannabichromene; THCV, tetrahydrocannabinol; GPR, G protein-coupled receptor; LPI, lysophosphatidylinositol; CBDV, cannabidivarin; NAGly, $\mathrm{N}$-arachidonyl glycine; TRPV2, transient receptor potential cation channel; subfamily V; member 2; IELs, intraepithelial lymphocytes; TRPA1, transient receptor potential cation channel; subfamily A; member 1; TRPM8, transient receptor potential cation channel; subfamily M, member 8.

et al. presented evidence that AEA inhibited expression of proinflammatory cytokines like IL-12 and IL-23 in in vitro models of immune disorders and increased the anti-inflammatory cytokine IL-10 in activated mouse microglia (137-139). In a model of acute intestinal inflammation it was shown that the transporter p-glycoprotein helped the influx of endocannabinoids into the intestinal lumen, which inhibited the migration of neutrophils by counteracting the pro-inflammatory neutrophil chemoattractant eicosanoid hepoxilin A3 (90). Similarly, the migration-related transcriptional profile of neutrophils was enhanced in $\mathrm{CB} 2^{-/-}$ mice. In response to Zymogen, the neutrophil, and lymphocyte antigen 6 complex was recruited to the dorsal air pouch and metalloproteinase 9 and CCL4 and CXCL10 increased (91).

\section{Regulation of the Immune Response by Phytocannabinoids}

Similarly, extracts of the phytocannabinoids CBD and THC could attenuate the proliferation of activated lymphocytes and the secretion of pro-inflammatory IL-17, thereby increasing secretion of the anti-inflammatory IL-10 (86). Additionally, the endocannabinoid AEA and the phytocannabinoid THC could also induce immunosuppression in B cells as was examined in both primary and secondary in vitro plaque-forming cell assays of antibody formation (93). Many reports have shown that exogenously applied CBD suppresses transcription factors involved in inflammation like NFAT, AP-1, and NF- $\kappa B$, which results in a broad repression of cytokines 


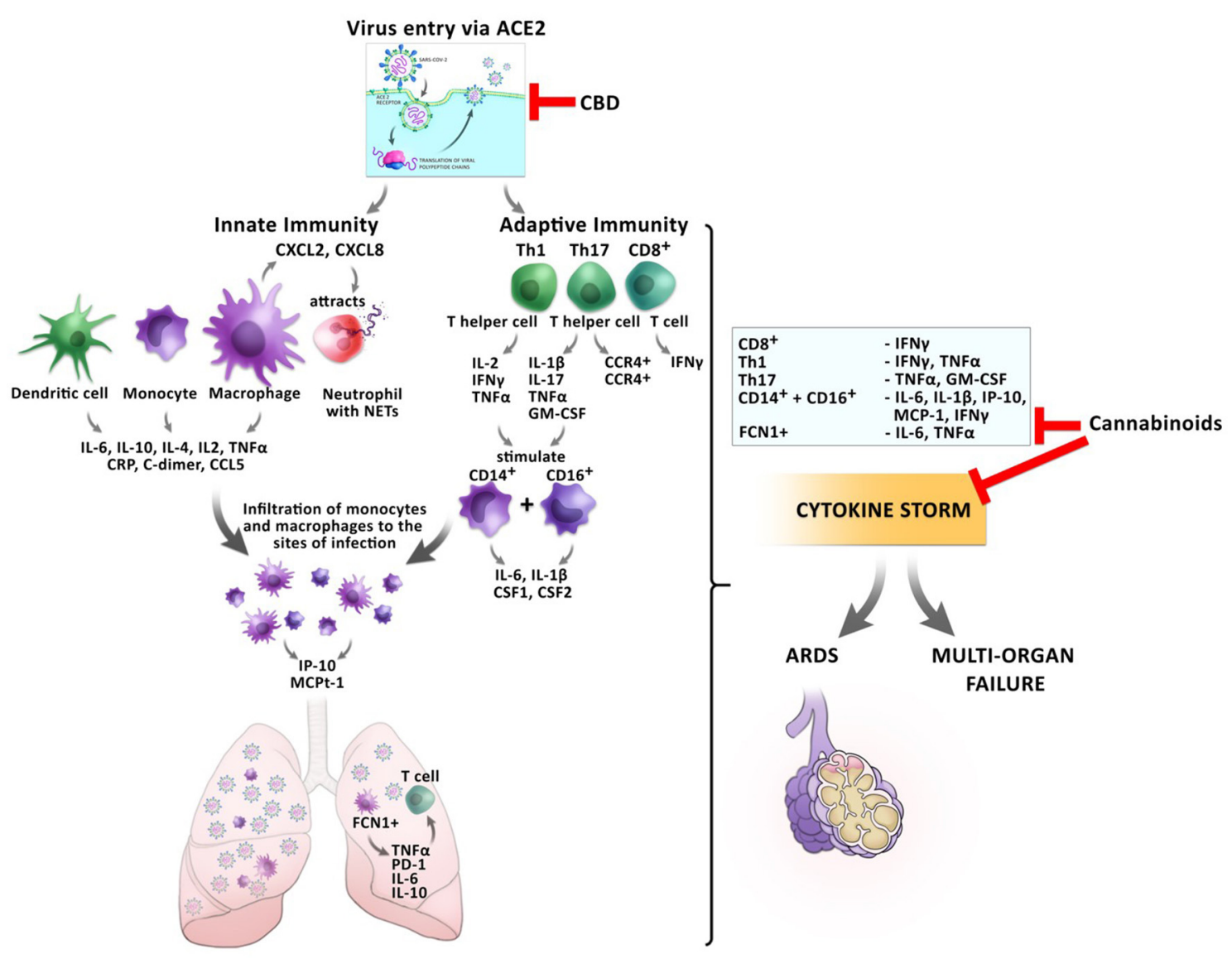

FIGURE 4 | Impact of cannabinoids on inflammatory responses during a SARS-CoV2 infection. The entry of the virus via ACE2 can be inhibited by CBD, reducing the virus load inside the cells. Infection with the virus triggers a cascade of inflammatory responses of the innate and adaptive immunity. Monocytes and macrophages secrete cytokines and chemokines. Activated macrophages secrete CXCL2 and CXCL8 which attract neutrophils, which release NETs to the site of infection.

Infiltrating FCN1 + macrophages secrete IL-6, IL-10, and TNF $\alpha$ in the lung, which leads to T cell apoptosis. CD8 ${ }^{+}$T cells secrete IFN $\gamma$ and TNF $\alpha$. Thelper cells Th1 and Th17 stimulate CD14+ and CD16+ monocytes to secrete IL-6, IL-1 $\beta$, and CSF1 and CSF2. This leads to the development of the cytokine storm, which might culminate in ARDS or multi-organ failure. Cannabinoids have the potential to inhibit the secretion of several pro-inflammatory cytokines resulting in prevention of CRS.

like IL-6, IL-1 $\beta$, IL-1 $\alpha$, GM-CSF, and TNF $\alpha$ in diverse cells and tissues (140). These cytokines have a central role in the development of CRS in COVID-19. IL-6 promotes the differentiation of Th17 cells, which was shown to be suppressed by CBD (141). Moreover, CBD was shown to inhibit IFN $\gamma$ (142).

A plethora of pre-clinical studies show that cannabinoids of certain cannabis strains can have an impact on the inflammatory response in mouse models of lung or inflammatory diseases, thus halting their progression. In a murine model of LPSinduced acute lung injury, CBD suppressed the vigorous immune response by three mechanisms: (i) inhibition of infiltration of leukocytes and neutrophils into lung tissue, (ii) inhibition of secretion of pro-inflammatory cytokines TNF $\alpha$, IL-6, and the chemokines MCP-1 and MIP-2 into the BALF, (iii) inhibition of the activity of myeloperoxidase, an enzyme with antimicrobial activity abundantly expressed in neutrophils (143). In murine models of chronic asthma, cytokine levels of IL-4, IL-5, IL-6, IL-13, and $\mathrm{TNF} \alpha$ were decreased by $\mathrm{CBD}$, probably exerting its effect via the CB1 receptor. This led to the reduction of airway inflammation and fibrosis $(144,145)$. Moreover, the production of regulatory $\mathrm{T}$ cells were increased in murine models of inflammatory diseases (146).

These anti-inflammatory actions of cannabis might be beneficial for the prevention of CRS before the host inflammatory response turns pathological during the transition from mild to critical disease in COVID-19 patients (Figure 4).

\section{CONCLUSION AND FUTURE PERSPECTIVES}

According to the current state of available clinical data, most severe COVID-19 symptoms are related to CRS, which is also assumed to be responsible for the fatal outcome in COVID-19 patients. Here, we discuss the hypothesis that cannabinoids may have a great potential for the inhibition of hyperinflammation leading to CRS in COVID-19 patients. However, extensive 
evidence from pre-clinical and clinical trials are still missing but urgently needed. This is because in spite of the medicinal potential of cannabis, it may be used in harmful or abusive manner. Cannabis is the most widely used illicit drug in the world. The United Nations Office On Drugs and Crime World Drug Report (UNODC) from 2020 measured around 192 million users in 2018 (147). An increased use among older adults was seen in the US between after legalization 2015 and 2018 (148) and known cannabis users increased their usage during first lockdown in the Netherlands (149) and in the US (150). The most common route of cannabis administration is smoking with or without tobacco. This raises concern in relation to the development of a severe/critical disease state in COVID19 patients because smoking tobacco upregulates ACE-2 which increases the entry rate of the virus into the cells and leads to a worse outcome (151). While in Europe still 77.2-90.9\% prefer tobacco-based smoking (152), the use of alternative routes of cannabis administration like vaporizing or edibles have increased in the US since legalization (153). However, whether vaping has an advantage over smoking for the likelihood of an infection with SARS-CoV2 and its outcome are still unknown (154).

Moreover, severe cardiovascular events were reported after acute usage of herbal cannabis (155) including an elevated risk of myocardial infarction in the presence of Angina pectoris (156) and reported cardiovascular deaths in $26 \%$ of users between 2006 and 2010 (157). In adolescent users, regular herbal cannabis use can lead to irreversible cognitive decline including loss of short-term memory, mood disorders, and schizophrenia (158).

However, increasing evidence shows a positive impact of cannabidiol on chronic pain in adult patients, as an antiemetic in chemotherapy-induced nausea and vomiting and in improving spasticity in multiple sclerosis based on patient's reports as well as in sleep improvement and fibromyalgia (159). However, many

\section{REFERENCES}

1. Huang C, Wang Y, Li X, Ren L, Zhao J, Hu Y, et al. Clinical features of patients infected with 2019 novel coronavirus in Wuhan, China. Lancet. (2020) 395:497-506. doi: 10.1016/S0140-6736(20)30183-5

2. Hoffmann M, Kleine-Weber H, Schroeder S, Krüger N, Herrler T, Erichsen $S$, et al. SARS-CoV-2 cell entry depends on ACE2 and TMPRSS2 and is blocked by a clinically proven protease inhibitor. Cell. (2020) 181:27180.e8. doi: 10.1016/j.cell.2020.02.052

3. Gheblawi M, Wang K, Viveiros A, Nguyen Q, Zhong J-C, Turner $\mathrm{AJ}$, et al. Angiotensin-converting enzyme 2: SARS-CoV-2 receptor and regulator of the renin-angiotensin system: celebrating the $20^{\text {th }}$ anniversary of the discovery of ACE2. Circ Res. (2020) 126:145674. doi: 10.1161/CIRCRESAHA.120.317015

4. Johnson KD, Harris C, Cain JK, Hummer C, Goyal H, Perisetti A. Pulmonary and extra-pulmonary clinical manifestations of COVID-19. Front Med. (2020) 7:526. doi: 10.3389/fmed.2020.00526

5. Perisetti A, Goyal H, Gajendran M, Boregowda U, Mann R, Sharma N. Prevalence, mechanisms, and implications of gastrointestinal symptoms in COVID-19. Front Med. (2020) 7:588711. doi: 10.3389/fmed.2020.588711

6. Mann R, Perisetti A, Gajendran M, Gandhi Z, Umapathy C, Goyal H. Clinical characteristics, diagnosis, and treatment of major coronavirus outbreaks. Front Med. (2020) 7:766. doi: 10.3389/fmed.2020.581521 more precisely targeted clinical studies need to be performed in order to evaluate the benefit/risk ratio for cannabinoids. All together, these concerns emphasize the need of deeper sciencebased data that will allow the appropriate use of cannabis for medicinal purposes. Our studies at the Medical Cannabis Research and Innovation Center follow this route. We aim to become more knowledgeable about the exact anti-inflammatory capability of the cannabinoid's components of a chosen strain with the lowest potential to drug abuse and the least adverse effects so that we can administer cannabinoids more accurately targeted to the patients.

\section{AUTHOR CONTRIBUTIONS}

IL-H and NP conceptualized the manuscript and established the writing consortium. AP wrote the section about the cannabinoid receptors. MA wrote the section about the anti-inflammatory properties of cannabinoids. $\mathrm{HH}, \mathrm{TP}$, and ES contributed to the writing and reviewing process. All authors contributed to the article and approved the submitted version.

\section{FUNDING}

This work was supported by RAMBAM MED-TECH Milestone Grant Raphael Pharmaceutical Inc. Cannabinoids and Inflammation Research Grant.

\section{ACKNOWLEDGMENTS}

We want to thank Raphael Pharmaceutical Inc. for supporting this study. Acknowledgments go to Dr. Avraham Shtevi for editing the manuscript and to Yotam Giladi for creating the figures.

7. Nanshan C, Zhou M, Dong X, Qu J, Gong F, Han Y, et al. Epidemiological and clinical characteristics of 99 cases of 2019 novel coronavirus pneumonia in Wuhan, China: a descriptive study. Lancet. (2020) 395:50713. doi: 10.1016/S0140-6736(20)30211-7

8. Wu Z, McGoogan JM. Characteristics of and important lessons from the coronavirus disease 2019 (COVID-19) outbreak in China: summary of a report of 72314 cases from the Chinese Center for Disease Control and Prevention. JAMA. (2020) 323:1239-42. doi: 10.1001/jama.2020. 2648

9. Richardson S, Hirsch Richardson S, Hirsch JS, Narasimhan M, Crawford JM, McGinn T, et al. Consortium and the NC-19 R. presenting characteristics, comorbidities, and outcomes among 5700 patients hospitalized with COVID-19 in the New York city area. JAMA. (2020) 323:205259. doi: 10.1001/jama.2020.6775

10. Wu C, Chen X, Cai Y, Xia J, Zhou X, Xu S, et al. Risk factors associated with acute respiratory distress syndrome and death in patients with coronavirus disease 2019 pneumonia in Wuhan, China. JAMA Intern Med. (2020) 180:934-43. doi: 10.1001/jamainternmed.2020.0994

11. Garg S, Kim L, Whitaker M, O'Halloran A, Cummings C, Holstein R, et al. Hospitalization rates and characteristics of patients hospitalized with laboratory-confirmed coronavirus disease 2019-COVID-NET, 14 States, March 1-30, 2020. MMWR Morb Mortal Wkly Rep. (2020) 69:45864. doi: $10.15585 / \mathrm{mmwr} . \mathrm{mm} 6915 \mathrm{e} 3$ 
12. Kopel J, Perisetti A, Roghani A, Aziz M, Gajendran M, Goyal H. Racial and gender-based differences in COVID-19. Front Public Heal. (2020) 8:418. doi: 10.3389/fpubh.2020.00418

13. Lucas C, Wong P, Klein J, Castro TBR, Silva J, Sundaram M, et al. Longitudinal analyses reveal immunological misfiring in severe COVID-19. Nature. (2020) 584:463-9. doi: 10.1038/s41586-0202588-y

14. Hadjadj J, Yatim N, Barnabei L, Corneau A, Boussier J, Pere H, et al. Impaired type I interferon activity and exacerbated inflammatory responses in severe Covid-19 patients. Science. (2020) 369:718-24. doi: 10.1101/2020.04.19.20068015

15. Merad M, Martin JC. Pathological inflammation in patients with COVID19: a key role for monocytes and macrophages. Nat Rev Immunol. (2020) 20:355-62. doi: 10.1038/s41577-020-0331-4

16. Franke L, (Severe C-19 GG). Genomewide association study of severe Covid-19 with respiratory failure. N Engl J Med. (2020) 383:152234. doi: 10.1056/NEJMoa2020283

17. Rabaan AA, Al-Ahmed SH, Sah R, Tiwari R, Yatoo MI, Patel SK, et al. SARSCoV-2/COVID-19 and advances in developing potential therapeutics and vaccines to counter this emerging pandemic. Ann Clin Microbiol Antimicrob. (2020) 19:40. doi: 10.1186/s12941-020-00384-w

18. Sharun K, Tiwari R, Iqbal Yatoo M, Patel SK, Natesan S, Dhama J,. Antibodybased immunotherapeutics and use of convalescent plasma to counter COVID-19: advances and prospects. Expert Opin Biol Ther. (2020) 20:103346. doi: 10.1080/14712598.2020.1796963

19. Keam S, Megawati D, Patel SK, Tiwari R, Dhama K, Harapan H. Immunopathology and immunotherapeutic strategies in severe acute respiratory syndrome coronavirus 2 infection. Rev Med Virol. (2020) 30:e2123-3. doi: 10.1002/rmv.2123

20. RECOVERY. No Clinical Benefit From Use of Lopinavir-Ritonavir in Hospitalised COVID-19 Patients Studied in RECOVERY. (2020). Available online at: https://www.recoverytrial.net/news/no-clinical-benefit-fromuse-of-lopinavir-ritonavir-in-hospitalised-covid-19-patients-studied-inrecovery (accessed September 14, 2020).

21. Group RC, Horby P, Mafham M, Linsell L, Bell JL, Staplin N, et al. Effect of hydroxychloroquine in hospitalized patients with Covid-19. N Engl J Med. (2020) 383:2030-40. doi: 10.1056/NEJMoa2022926

22. Agarwal A, Mukherjee A, Kumar G, Chatterjee P, Bhatnagar T, Malhotra P. Convalescent plasma in the management of moderate covid-19 in adults in India: open label phase II multicentre randomised controlled trial (PLACID Trial). Br Med J. (2020) 371:m3939. doi: 10.1136/bmj.m3939

23. Gould J. The Cannabis Crop. Nature. (2015) 525:S2-3. doi: 10.1038/525S2a

24. Andre CM, Hausman J-F, Guerriero G. Cannabis sativa: the plant of the thousand and one molecules. Front Plant Sci. (2016) 7:19. doi: 10.3389/fpls.2016.00019

25. Mechoulam R, Hanuš LO, Pertwee R, Howlett AC. Early phytocannabinoid chemistry to endocannabinoids and beyond. Nat Rev Neurosci. (2014) 15:757-64. doi: 10.1038/nrn3811

26. Costiniuk CT, Saneei Z, Routy J-P, Margolese S, Mandarino E, Singer J, et al. Oral cannabinoids in people living with HIV on effective antiretroviral therapy: CTN PT028-study protocol for a pilot randomised trial to assess safety, tolerability and effect on immune activation. BMJ Open. (2019) 9:e024793. doi: 10.1136/bmjopen-2018-024793

27. Lowe HIC, Toyang NJ, McLaughlin W. Potential of cannabidiol for the treatment of viral hepatitis. Pharmacognosy Res. (2017) 9:1168. doi: 10.4103/0974-8490.199780

28. Karmaus PWF, Chen W, Crawford R, Kaplan BLF, Kaminski NE. $\Delta 9$ tetrahydrocannabinol impairs the inflammatory response to influenza infection: role of antigen-presenting cells and the cannabinoid receptors 1 and 2. Toxicol Sci. (2013) 131:419-33. doi: 10.1093/toxsci/kfs315

29. Buchweitz J, Karamaus P, Williams K, Harkema J, Kaminsky N. Targeted deletion of cannabinoid receptors $\mathrm{CB} 1$ and $\mathrm{CB} 2$ produced enhanced inflammatory responses to influenza $\mathrm{A} / \mathrm{PR} / 8 / 34$ in the absence and presence of D9-tetrahydrocannabinol. J Leukoc Biol. (2008) 83:785-96. doi: 10.1189/jlb.0907618

30. Tahamtan A, Tavakoli-Yaraki M, Rygiel TP, Mokhtari-Azad T, Salimi V. Effects of cannabinoids and their receptors on viral infections. J Med Virol. (2016) 88:1-12. doi: 10.1002/jmv.24292
31. Grant RA, Morales-Nebreda L, Markov NS, Swaminathan S, Querrey M, Guzman ER, et al. Circuits between infected macrophages and T cells in SARS-CoV-2 pneumonia. Nature. (2021). doi: 10.1038/s41586-020-03148-w

32. Dorward DA, Russell CD, Um IH, Elshani M, Armstrong SD, Penrice-Randal $\mathrm{R}$, et al. Tissue-specific tolerance in fatal Covid-19. Am J Respir Crit Care Med. (2020). 203:192-201. doi: 10.1101/2020.07.02.20145003

33. Liu J, Liu Y, Xiang P, Pu L, Xiong H, Li C, et al. Neutrophil-to-lymphocyte ratio predicts critical illness patients with 2019 coronavirus disease in the early stage. J Transl Med. (2020) 18:206. doi: 10.1186/s12967-02002374-0

34. Liao M, Liu Y, Yuan J, Wen Y, Xu G, Zhao J, et al. Single-cell landscape of bronchoalveolar immune cells in patients with COVID-19. Nat Med. (2020) 26:842-4. doi: 10.1038/s41591-020-0901-9

35. Dhama K, Patel SK, Pathak M, Yatoo MI, Tiwari R, Malik YS, et al. An update on SARS-CoV-2/COVID-19 with particular reference to its clinical pathology, pathogenesis, immunopathology and mitigation strategies. Travel Med Infect Dis. (2020) 37:101755. doi: 10.1016/j.tmaid.2020.101755

36. Vaduganathan M, Vardeny O, Michel T, McMurray JJ V, Pfeffer MA, Solomon SD. Renin-angiotensin-aldosterone system inhibitors in patients with Covid-19. N Engl J Med. (2020) 382:1653-9. doi: 10.1056/NEJMsr2005760

37. Verdecchia P, Cavallini C, Spanevello A, Angeli F. The pivotal link between ACE2 deficiency and SARS-CoV-2 infection. Eur J Intern Med. (2020) 74:14-20. doi: 10.1016/j.ejim.2020.04.037

38. Chen Y, Feng Z, Diao B, Wang R, Wang G, Wang C, et al. The novel severe acute respiratory syndrome coronavirus 2 (SARS-CoV-2) directly decimates human spleens and lymph nodes. medRxiv [Preprint]. (2020). doi: 10.1101/2020.03.27.20045427

39. Honke N, Shaabani N, Cadeddu G, Sorg UR, Zhang D-E, Trilling $\mathrm{M}$, et al. Enforced viral replication activates adaptive immunity and is essential for the control of a cytopathic virus. Nat Immunol. (2012) 13:5157. doi: 10.1038/ni.2169

40. Park MD. Macrophages: a Trojan horse in COVID-19? Nat Rev Immunol. (2020) 20:351. doi: 10.1038/s41577-020-0317-2

41. Channappanavar R, Fehr AR, Vijay R, Mack M, Zhao J, Meyerholz DK, et al. Dysregulated type I interferon and inflammatory monocyte-macrophage responses cause lethal pneumonia in SARS-CoV-infected mice. Cell Host Microbe. (2016) 19:181-93. doi: 10.1016/j.chom.2016.01.007

42. Xiong Y, Liu Y, Cao L, Wang D, Guo M, Jiang A, et al. Transcriptomic characteristics of bronchoalveolar lavage fluid and peripheral blood mononuclear cells in COVID-19 patients. Emerg Microbes Infect. (2020) 9:761-70. doi: 10.1080/22221751.2020.1747363

43. Koenig LM, Boehmer DFR, Metzger P, Schnurr M, Endres S, Rothenfusser S. Blocking inflammation on the way: rationale for CXCR2 antagonists for the treatment of COVID-19. J Exp Med. (2020) 217:e20201342. doi: 10.1084/jem.20201342

44. Zuo Y, Yalavarthi S, Shi H, Gockman K, Zuo M, Madison JA, et al. Neutrophil extracellular traps in COVID-19. JCI Insight. (2020) 5:e138999. doi: 10.1172/jci.insight.138999

45. Qin C, Zhou L, Hu Z, Zhang S, Yang S, Tao Y, et al. Dysregulation of immune response in patients with COVID-19 in Wuhan, China. Clin Infect Dis. (2020) 71:762-8. doi: 10.1093/cid/ciaa248

46. Wen W, Su W, Tang H, Le W, Zhang X, Zheng Y, et al. Immune cell profiling of COVID-19 patients in the recovery stage by single-cell sequencing. Cell Discov. (2020) 6:31. doi: 10.1038/s41421-020-0168-9

47. Gupta S, Bi R, Kim C, Chiplunkar S, Yel L, Gollapudi S. Role of $N F-\kappa B$ signaling pathway in increased tumor necrosis factor- $\alpha$-induced apoptosis of lymphocytes in aged humans. Cell Death Differ. (2005) 12:177183. doi: $10.1038 /$ sj.cdd.4401557

48. Davis GS, Brody AR, Craighead JE. Analysis of airspace and interstitial mononuclear cell populations in human diffuse interstitial lung disease. Am Rev Respir Dis. (1978) 118:7-15. doi: 10.1164/arrd.1978.118.1.7

49. Weiskopf D, Schmitz KS, Raadsen MP, Grifoni A, Okba NMA, Endeman $\mathrm{H}$, et al. Phenotype of SARS-CoV-2-specific T-cells in COVID-19 patients with acute respiratory distress syndrome. Sci Immunol. (2020) 5:eabd2071. doi: 10.1101/2020.04.11.20062349

50. Zheng H-Y, Zhang M, Yang C-X, Zhang N, Wang X-C, Yang X-P, et al. Elevated exhaustion levels and reduced functional diversity of $\mathrm{T}$ cells in 
peripheral blood may predict severe progression in COVID-19 patients. Cell Mol Immunol. (2020) 17:541-3. doi: 10.1038/s41423-020-0401-3

51. Xu Z, Shi L, Wang Y, Zhang J, Huang L, Zhang C, et al. Pathological findings of COVID-19 associated with acute respiratory distress syndrome. Lancet Respir Med. (2020) 8:420-422. doi: 10.1016/S2213-2600(20)30076-X

52. Schorer M, Lambert K, Rakebrandt N, Rost F, Kao K-C, Yermanos A, et al. Rapid expansion of Treg cells protects from collateral colitis following a viral trigger. Nat Commun. (2020) 11:1522. doi: 10.1038/s41467-020-15309-6

53. Zhang D, Guo R, Lei L, Liu H, Wang Y, Wang Y, et al. COVID-19 infection induces readily detectable morphologic and inflammation-related phenotypic changes in peripheral blood monocytes. J Leukoc Biol. (2020) 109:13-22. doi: 10.1002/JLB.4HI0720-470R

54. Chen X, Zhao B, Qu Y, Chen Y, Xiong J, Feng Y, et al. Detectable serum severe acute respiratory syndrome coronavirus 2 viral load (RNAemia) is closely correlated with drastically elevated interleukin 6 level in critically ill patients with coronavirus disease 2019. Clin Infect Dis. (2020) 71:193742. doi: $10.1093 / \mathrm{cid} / \mathrm{ciaa} 449$

55. Kerr R, Stirling D, Ludlam CA. Interleukin 6 and haemostasis. Br J Haematol. (2001) 115:3-12. doi: 10.1046/j.1365-2141.2001.03061.x

56. Wu D, Yang XO. TH17 responses in cytokine storm of COVID-19: an emerging target of JAK2 inhibitor Fedratinib. J Microbiol Immunol Infect. (2020) 53:368-70. doi: 10.1016/j.jmii.2020.03.005

57. Liu Y, Zhang C, Huang F, Yang Y, Wang F, Yuan J, et al. Elevated plasma levels of selective cytokines in COVID-19 patients reflect viral load and lung injury. Natl Sci Rev. (2020) 7:1003-11. doi: 10.1093/nsr/nwaa037

58. Chen G, Wu D, Guo W, Cao Y, Huang D, Wang H, et al. Clinical and immunological features of severe and moderate coronavirus disease 2019. J Clin Invest. (2020) 130:2620-9. doi: 10.1172/JCI137244

59. Wang J, Jiang $\mathrm{M}$, Chen $\mathrm{X}$, Montaner LJ. Cytokine storm and leukocyte changes in mild versus severe SARS-CoV-2 infection: review of 3939 COVID-19 patients in China and emerging pathogenesis and therapy concepts. J Leukoc Biol. (2020) 108:17-41. doi: 10.1002/JLB.3COVR0520-272R

60. Sterne, Jonathan AC, Murthy S, Diaz JV, Slutsky AS, Villar J, et al. Association between administration of systemic corticosteroids and mortality among critically ill patients with COVID-19: a meta-analysis. JAMA. (2020) 324:113. doi: $10.1001 /$ jama.2020.17023

61. Sharun K, Tiwari R, Dhama J, Dhama K. Dexamethasone to combat cytokine storm in COVID-19: clinical trials and preliminary evidence. Int J Surg. (2020) 82:179-81. doi: 10.1016/j.ijsu.2020.08.038

62. Stebbing J, Phelan A, Griffin I, Tucker C, Oechsle O, Smith D, et al. COVID19: combining antiviral and anti-inflammatory treatments. Lancet Infect Dis. (2020) 20:400-2. doi: 10.1016/S1473-3099(20)30132-8

63. Soy M, Keser G, Atagündüz P, Tabak F, Atagündüz I, Kayhan S. Cytokine storm in COVID-19: pathogenesis and overview of antiinflammatory agents used in treatment. Clin Rheumatol. (2020) 39:208594. doi: 10.1007/s10067-020-05190-5

64. Boregowda U, Perisetti A, Nanjappa A, Gajendran M, Kutti Sridharan G, Goyal H. Addition of tocilizumab to the standard of care reduces mortality in severe COVID-19: a systematic review and meta-analysis. Front Med. (2020) 7:586221. doi: $10.3389 /$ fmed.2020.586221

65. Liu B, Li M, Zhou Z, Guan X, Xiang Y. Can we use interleukin6 (IL-6) blockade for coronavirus disease 2019 (COVID-19)induced cytokine release syndrome (CRS)? J Autoimmun. (2020) 111:102452. doi: 10.1016/j.jaut.2020.102452

66. Baum A, Copin R, Ajithdoss D, Zhou A, Lanza K, Negron N, et al. REGN-COV2 antibody cocktail prevents and treats SARS-CoV-2 infection in rhesus macaques and hamsters. Science. (2020) 370:1110-5. doi: $10.1101 / 2020.08 .02 .233320$

67. Beigel JH, Tomashek KM, Dodd LE, Mehta AK, Zingman BS, Kalil AC, et al. Remdesivir for the Treatment of Covid-19-preliminary report. N Engl J Med. (2020) 383:1813-26. doi: 10.1056/nejmoa2007764

68. White NJ, Watson JA, Hoglund RM, Chan XHS, Cheah PY, Tarning J. COVID-19 prevention and treatment: a critical analysis of chloroquine and hydroxychloroquine clinical pharmacology. PLoS MED. (2020) 17:e1003252. doi: 10.1371/journal.pmed.1003445

69. Aguila EJT, Cua IHY. Repurposed GI drugs in the treatment of COVID-19. Dig Dis Sci. (2020) 65:2452-3. doi: 10.1007/s10620-020-06430-z
70. Byrareddy SN, Mohan M. SARS-CoV2 induced respiratory distress: can cannabinoids be added to anti-viral therapies to reduce lung inflammation? Brain Behav Immun. (2020) 87:120-1. doi: 10.1016/j.bbi.2020. 04.079

71. Esposito G, Pesce M, Seguella L, Sanseverino W, Lu J, Corpetti C, et al. The potential of cannabidiol in the COVID-19 pandemic. Br J Pharmacol. (2020) 177:4967-70. doi: 10.1111/bph.15157

72. Sexton M. Cannabis in the time of coronavirus disease 2019: the Yin and Yang of the endocannabinoid system in immunocompetence. J Altern Complement Med. (2020) 26:444-8. doi: 10.1089/acm.2020.0144

73. Pain S. A potted history. Nature. (2015) 525:S10-S11. doi: 10.1038/525S10a

74. Mechoulam R, Ben-Shabat S, Hanus L, Ligumsky M, Kaminski NE, Schatz $\mathrm{AR}$, et al. Identification of an endogenous 2-monoglyceride, present in canine gut, that binds to cannabinoid receptors. Biochem Pharmacol. (1995) 50:83-90. doi: 10.1016/0006-2952(95)00109-D

75. Stella N, Schweitzer P, Piomelli D. A second endogenous cannabinoid that modulates long-term potentiation. Nature. (1997) 388:773-77.

76. Chiurchiù V, Battistini L, Maccarrone M. Endocannabinoid signalling in innate and adaptive immunity. Immunology. (2015) 144:352-64. doi: 10.1111/imm.12441

77. Murataeva N, Straiker A, Mackie K. Parsing the players: 2arachidonoylglycerol synthesis and degradation in the CNS. Br J Pharmacol. (2014) 171:1379-91. doi: 10.1111/bph.12411

78. Farooqui AA, Rammohan KW, Horrocks LA. Isolation, characterization, and regulation of diacylglycerol lipases from the bovine brain. Ann N Y Acad Sci. (1989) 559:25-36. doi: 10.1111/j.1749-6632.1989.tb22596.x

79. Bisogno T, Howell F, Williams G, Minassi A, Cascio MG, Ligresti A, et al. Cloning of the first sn1-DAG lipases points to the spatial and temporal regulation of endocannabinoid signaling in the brain. J Cell Biol. (2003) 163:463-8. doi: 10.1083/jcb.200305129

80. Blankman JL, Simon GM, Cravatt BF. A comprehensive profile of brain enzymes that hydrolyze the endocannabinoid 2-arachidonoylglycerol. Chem Biol. (2007) 14:1347-56. doi: 10.1016/j.chembiol.2007.11.006

81. Okamoto Y, Morishita J, Tsuboi K, Tonai T, Ueda N. Molecular characterization of a phospholipase D generating anandamide and its congeners. J Biol Chem. (2004) 279:5298-305. doi: 10.1074/jbc.M306642200

82. McKinney MK, Cravatt BF. Structure and function of fatty acid amide hydrolase. Annu Rev Biochem. (2005) 74:41132. doi: 10.1146/annurev.biochem.74.082803.133450

83. Zou S, Kumar U. Cannabinoid receptors and the endocannabinoid system: signaling and function in the central nervous system. Int J Mol Sci. (2018) 19:833. doi: 10.3390/ijms19030833

84. Benito C, Tolón RM, Pazos MR, Núñez E, Castillo AI, Romero J. Cannabinoid CB2 receptors in human brain inflammation. Br J Pharmacol. (2008) 153:277-85. doi: 10.1038/sj.bjp.0707505

85. Hoggatt J, Pelus LM. Eicosanoid regulation of hematopoiesis and hematopoietic stem and progenitor trafficking. Leukemia. (2010) 24:19932002. doi: 10.1038/leu.2010.216

86. Khuja I, Yekhtin Z, Or R, Almogi-Hazan O. Cannabinoids reduce inflammation but inhibit lymphocyte recovery in murine models of bone marrow transplantation. Int J Mol Sci. (2018) 20:668. doi: 10.3390/ijms20030668

87. Starnes T, Broxmeyer HE, Robertson MJ, Hromas R. Cutting Edge: IL-17D, a novel member of the IL-17 family, stimulates cytokine production and inhibits hemopoiesis. J Immunol. (2002) 169:6426. doi: 10.4049/jimmunol.169.2.642

88. Chiricozzi A, Guttman-Yassky E, Suárez-Fariñas M, Nograles KE, Tian S, Cardinale I, et al. Integrative responses to IL-17 and TNF- $\alpha$ in human keratinocytes account for key inflammatory pathogenic circuits in psoriasis. J Invest Dermatol. (2011) 131:677-87. doi: 10.1038/jid.2010.340

89. Miossec P, Korn T, Kuchroo VK. Interleukin-17 and type 17 helper T cells. $N$ Engl J Med. (2009) 361:888-98. doi: 10.1056/NEJMra0707449

90. Szabady RL, Louissaint C, Lubben A, Xie B, Reeksting S, Tuohy C, et al. Intestinal P-glycoprotein exports endocannabinoids to prevent inflammation and maintain homeostasis. J Clin Invest. (2018) 128:404456. doi: 10.1172/JCI96817

91. Kapellos TS, Taylor L, Feuerborn A, Valaris S, Hussain MT, Rainger GE, et al. Cannabinoid receptor 2 deficiency exacerbates inflammation and 
neutrophil recruitment. FASEB J. (2019) 33:6154-67. doi: 10.1096/fj.20180 2524R

92. Pereira JP, An J, Xu Y, Huang Y, Cyster JG. Cannabinoid receptor 2 mediates the retention of immature B cells in bone marrow sinusoids. Nat Immunol. (2009) 10:403-11. doi: 10.1038/ni.1710

93. Eisenstein TK, Meissler JJ, Wilson Q, Gaughan JP, Adler MW. Anandamide and Delta9-tetrahydrocannabinol directly inhibit cells of the immune system via CB2 receptors. J Neuroimmunol. (2007) 189:17-22. doi: 10.1016/j.jneuroim.2007.06.001

94. Sugiura T, Kondo S, Sukagawa A, Nakane S, Shinoda A, Itoh K, et al. 2-arachidonoylgylcerol: a possible endogenous cannabinoid receptor ligand in brain. Biochem Biophys Res Commun. (1995) 215:89-97. doi: 10.1006/bbrc.1995.2437

95. Devane WA, Hanus L, Breuer A, Pertwee RG, Stevenson LA, Griffin G. Isolation and structure of a brain constituent that binds to the cannabinoid receptor. Science. (1992) 258:1946-9. doi: 10.1126/science.1470919

96. Boychuk DG, Goddard G, Mauro G, Orellana MF. The effectiveness of cannabinoids in the management of chronic nonmalignant neuropathic pain: a systematic review. J Oral Facial Pain Headache. (2015) 29:714. doi: $10.11607 /$ ofph. 1274

97. De Petrocellis L, Ligresti A, Moriello AS, Allarà M, Bisogno T, Petrosino S, et al. Effects of cannabinoids and cannabinoid-enriched Cannabis extracts on TRP channels and endocannabinoid metabolic enzymes. Br J Pharmacol. (2011) 163:1479-94. doi: 10.1111/j.1476-5381.2010.01166.x

98. Novack GD. Cannabinoids for treatment of glaucoma. Curr Opin Ophthalmol. (2016) 27:146-50. doi: 10.1097/ICU.00000000000002:

99. JÄrbe TUC, Henriksson BG. Effects of $\triangle 8$-THC, and $\triangle 9$-THC on the acquisition of a discriminative positional habit in rats. Psychopharmacologia. (1973) 31:321-32. doi: 10.1007/BF00421276

100. Rhee M-H, Vogel Z, Barg J, Bayewitch M, Levy R, Hanuš L, et al. Cannabinol derivatives: binding to cannabinoid receptors and inhibition of adenylylcyclase. J Med Chem. (1997) 40:3228-33. doi: 10.1021/jm970126f

101. Kathmann M, Flau K, Redmer A, Tränkle C, Schlicker E. Cannabidiol is an allosteric modulator at mu- and deltaopioid receptors. Naunyn Schmiedebergs Arch Pharmacol. (2006) 372:354-61. doi: 10.1007/s00210-006-0033-x

102. Scuderi C, Steardo L, Esposito G. Cannabidiol promotes amyloid precursor protein ubiquitination and reduction of beta amyloid expression in SHSY5YAPP+ cells through PPAR $\gamma$ involvement. Phyther Res. (2014) 28:1007-13. doi: 10.1002/ptr.5095

103. Esposito G, Scuderi C, Valenza M, Togna GI, Latina V, De Filippis D, et al. Cannabidiol reduces $A \beta$-induced neuroinflammation and promotes hippocampal neurogenesis through PPAR $\gamma$ involvement. PLoS ONE. (2011) 6:e28668. doi: 10.1371/journal.pone.0028668

104. Rosenthaler S, Pöhn B, Kolmanz C, Huu CN, Krewenka C, Huber A, et al. Differences in receptor binding affinity of several phytocannabinoids do not explain their effects on neural cell cultures. Neurotoxicol Teratol. (2014) 46:49-56. doi: 10.1016/j.ntt.2014.09.003

105. Flegel C, Vogel F, Hofreuter A, Wojcik S, Schoeder C, Kieć-Kononowicz K, et al. Characterization of non-olfactory GPCRs in human sperm with a focus on GPR18. Sci Rep. (2016) 6:32255. doi: 10.1038/srep32255

106. Kohno M, Hasegawa H, Inoue A, Muraoka M, Miyazaki T, Oka K, et al. Identification of $\mathrm{N}$-arachidonylglycine as the endogenous ligand for orphan G-protein-coupled receptor GPR18. Biochem Biophys Res Commun. (2006) 347:827-32. doi: 10.1016/j.bbrc.2006.06.175

107. Becker AM, Callahan DJ, Richner JM, Choi J, DiPersio JF, Diamond MS, et al. GPR18 controls reconstitution of mouse small intestine intraepithelial lymphocytes following bone marrow transplantation. PLOS ONE. (2015) 10:e0133854. doi: 10.1371/journal.pone.0133854

108. McHugh D, Page J, Dunn E, Bradshaw HB. $\Delta$ 9-THC and N-arachidonyl glycine are full agonists at GPR18 and cause migration in the human endometrial cell line, HEC-1B. Br J Pharmacol. (2012) 165:2414-24. doi: 10.1111/j.1476-5381.2011.01497.x

109. Sumida H, Lu E, Chen H, Yang Q, Mackie K, Cyster JG. GPR55 regulates intraepithelial lymphocyte migration dynamics and susceptibility to intestinal damage. Sci Immunol. (2017) 2:eaao1135. doi: 10.1126/sciimmunol.aao1135
110. Whyte LS, Ryberg E, Sims NA, Ridge SA, Mackie K, Greasley PJ, et al. The putative cannabinoid receptor GPR55 affects osteoclast function in vitro and bone mass in vivo. Proc Natl Acad Sci U S A. (2009) 106:165116. doi: 10.1073/pnas.0902743106

111. Ryberg E, Larsson N, Sjögren S, Hjorth S, Hermansson N-O, Leonova J, et al. The orphan receptor GPR55 is a novel cannabinoid receptor. Br J Pharmacol. (2007) 152:1092-101. doi: 10.1038/sj.bjp.0707460

112. Howlett AC, Barth F, Bonner TI, Cabral G, Casellas P, Devane WA, et al. International union of pharmacology. XXVII. Classification of cannabinoid receptors. Pharmacol Rev. (2002) 54:161-202. doi: 10.1124/pr. 54.2 .161

113. Lauckner JE, Jensen JB, Chen H-Y, Lu H-C, Hille B, Mackie K. GPR55 is a cannabinoid receptor that increases intracellular calcium and inhibits M current. Proc Natl Acad Sci U S A. (2008) 105:2699704. doi: 10.1073/pnas.0711278105

114. Blair NT, Carvacho I, Chaudhuri D, Clapham DE, DeCaen P, Delling M, et al. Transient receptor potential channels (version 2019.4) in the IUPHAR/BPS guide to pharmacology database. IUPHAR/BPS Guid to Pharmacol CITE. (2019) 1-59. doi: 10.2218/gtopdb/F78/2019.4

115. Nabissi M, Morelli MB, Santoni M, Santoni G. Triggering of the TRPV2 channel by cannabidiol sensitizes glioblastoma cells to cytotoxic chemotherapeutic agents. Carcinogenesis. (2012) 34:48-57. doi: 10.1093/carcin/bgs328

116. Sullivan SE, Kendall DA, Randall MD. Further characterization of the timedependent vascular effects of $\Delta 9$-tetrahydrocannabinol. J Pharmacol Exp Ther. (2006) 317:428-438. doi: 10.1124/jpet.105.095828

117. Mukhopadhyay I, Gomes P, Aranake S, Shetty M, Karnik P, Damle $\mathrm{M}$, et al. Expression of functional TRPA1 receptor on human lung fibroblast and epithelial cells. J Recept Signal Transduct. (2011) 31:350358. doi: 10.3109/10799893.2011.602413

118. Vara D, Morell C, Rodríguez-Henche N, Diaz-Laviada I. Involvement of PPAR $\gamma$ in the antitumoral action of cannabinoids on hepatocellular carcinoma. Cell Death Dis. (2013) 4:e618. doi: 10.1038/cddis. 2013.141

119. Hirai A, Aung NY, Ohe R, Nishida A, Kato T, Meng H, et al. Expression of TRPM8 in human reactive lymphoid tissues and mature B-cell neoplasms. Oncol Lett. (2018) 16:5930-8. doi: 10.3892/ol.2018.9386

120. McKemy DD. How cold is it? TRPM8 and TRPA1 in the molecular logic of cold sensation. Mol Pain. (2005) 1:16. doi: 10.1186/1744-8069-1-16

121. Rosenbaum DM, Rasmussen SGF, Kobilka BK. The structure and function of G-protein-coupled receptors. Nature. (2009) 459:356-63. doi: 10.1038/nature08144

122. Yu FH, Catterall WA. The VGL-chanome: a protein superfamily specialized for electrical signaling and ionic homeostasis. Sci STKE. (2004) 2004:re15. doi: 10.1126/stke.2532004re15

123. Moran MM, McAlexander MA, Bíró T, Szallasi A. Transient receptor potential channels as therapeutic targets. Nat Rev Drug Discov. (2011) 10:601-20. doi: 10.1038/nrd3456

124. Caterina MJ. TRP channel cannabinoid receptors in skin sensation, homeostasis, and inflammation. ACS Chem Neurosci. (2014) 5:110716. doi: $10.1021 / \mathrm{cn} 5000919$

125. Nilius B, Owsianik G. Transient receptor potential channelopathies. Pflügers Arch Eur J Physiol. (2010) 460:437-50. doi: 10.1007/s00424-010-0788-2

126. Storozhuk MV, Zholos AV TRP channels as novel targets for endogenous ligands: focus on endocannabinoids and nociceptive signalling. Curr Neuropharmacol. (2018) 16:13750. doi: 10.2174/1570159X15666170424120802

127. Orio LP, Boschin G, Recca T, Morelli CF, Ragona L, Francescato P, et al. New ACE-inhibitory peptides from hemp seed (Cannabis sativa L.) proteins. J Agric Food Chem. (2017) 65:10482-8. doi: 10.1021/acs.jafc.7b04522

128. Wang B, Kovalchuk A, Li D, Ilnytskyy Y, Kovalchuk I, Kovalchuk O. In search of preventative strategies: novel anti-inflammatory high-CBD Cannabis sativa extracts modulate ACE2 expression in COVID-19 gateway tissues. Preprints. (2020). doi: 10.20944/preprints202004.0315.v1

129. Anil SM, Shalev N, Vinayaka AC, Nadarajan S, Namdar D, Belausov E, et al. Cannabis compounds exhibit anti-inflammatory activity in vitro in COVID-19-related inflammation in lung epithelial cells 
and pro-inflammatory activity in macrophages. Sci Rep. (2021) 11:1462. doi: 10.1038/s41598-021-81049-2

130. Khodadadi H, Salles ÉL, Jarrahi A, Chibane F, Costigliola V, Yu JC, et al. Cannabidiol modulates cytokine storm in acute respiratory distress syndrome induced by simulated viral infection using synthetic RNA. Cannabis Cannabinoid Res. (2020) 5:197-201. doi: 10.1089/can.2020.0043

131. Salles ÉL, Khodadadi H, Jarrahi A, Ahluwalia M, Paffaro VA, Costigliola V, et al. Cannabidiol (CBD) modulation of apelin in acute respiratory distress syndrome. J Cell Mol Med. (2020) 24:12869-72. doi: 10.1111/jcmm.15883

132. Köse S, Aerts-Kaya F, Köprü ÇZ, Nemutlu E, Kuşkonmaz B, Karaosmanoglu $B$, et al. Human bone marrow mesenchymal stem cells secrete endocannabinoids that stimulate in vitro hematopoietic stem cell migration effectively comparable to beta-adrenergic stimulation. Exp Hematol. (2018) 57:30-41.e1. doi: 10.1016/j.exphem.2017.09.009

133. Almogi-Hazan O, Or R. Cannabis, the endocannabinoid system and immunity-the journey from the bedside to the bench and back. Int J Mol Sci. (2020) 21:4448. doi: 10.3390/ijms21124448

134. Sido JM, Nagarkatti PS, Nagarkatti M. Production of endocannabinoids by activated $\mathrm{T}$ cells and $\mathrm{B}$ cells modulates inflammation associated with delayed-type hypersensitivity. Eur J Immunol. (2016) 46:14729. doi: $10.1002 /$ eji.201546181

135. Dotsey E, Ushach I, Pone E, Nakajima R, Jasinskas A, Argueta DA, et al. Transient cannabinoid receptor 2 blockade during immunization heightens intensity and breadth of antigen-specific antibody responses in young and aged mice. Sci Rep. (2017) 7:42584. doi: 10.1038/srep42584

136. Cabral GA, Toney DM, Fischer-Stenger K, Harrison MP, Marciano-Cabral F. Anandamide inhibits macrophage-mediated killing of tumor necrosis factor-sensitive cells. Life Sci. (1995) 56:2065-72. doi: 10.1016/0024-3205(95)00190-H

137. Correa F, Henangomez-Herrero M, Mestre L, Loria F, Docagne F, Guaza C. The endocannabinoid anandamide downregulates IL-23 and IL-12 subunits in a viral model of multiple sclerosis: evidence for a cross-talk between IL12p70/IL-23 axis and IL-10 in microglial cells. Brain, Behav Immun. (2011) 25:736-49. doi: 10.1016/j.bbi.2011.01.020

138. Correa F, Docagne F, Clemente D, Mestre L, Becker C, Guaza C. Anandamide inhibits IL-12p40 production by acting on the promoter repressor element GA-12: possible involvement of the COX-2 metabolite prostamide E2. Biochem J. (2008) 409:761-70. doi: 10.1042/BJ20071329

139. Correa F, Hernangómez M, Mestre L, Loría F, Spagnolo A, Docagne F, et al. Anandamide enhances IL-10 production in activated microglia by targeting CB2 receptors: roles of ERK1/2, JNK, and NF-кB. Glia. (2010) 58:135-47. doi: 10.1002/glia.20907

140. Nichols JM, Kaplan BLF. Immune responses regulated by cannabidiol. Cannabis Cannabinoid Res. (2019) 5:12-31. doi: 10.1089/can.2018.0073

141. Zgair A, Lee JB, Wong JCM, Taha DA, Aram J, Di Virgilio D, et al. Oral administration of cannabis with lipids leads to high levels of cannabinoids in the intestinal lymphatic system and prominent immunomodulation. Sci Rep. (2017) 7:14542. doi: 10.1038/s41598-017-15026-z

142. Kaplan BLF, Springs AEB, Kaminski NE. The profile of immune modulation by cannabidiol (CBD) involves deregulation of nuclear factor of activated T cells (NFAT). Biochem Pharmacol. (2008) 76:72637. doi: $10.1016 /$ j.bcp.2008.06.022

143. Ribeiro A, Almeida VI, Costola-de-Souza C, Ferraz-de-Paula V, Pinheiro ML, Vitoretti LB, et al. Cannabidiol improves lung function and inflammation in mice submitted to LPS-induced acute lung injury. Immunopharmacol Immunotoxicol. (2015) 37:35-41. doi: 10.3109/08923973.2014.976794

144. Vuolo F, Petronilho F, Sonai B, Ritter C, Hallak JEC, Zuardi AW, et al. Evaluation of serum cytokines levels and the role of cannabidiol treatment in animal model of asthma. Mediators Inflamm. (2015) 2015:538670. doi: 10.1155/2015/538670

145. Vuolo F, Abreu SC, Michels M, Xisto DG, Blanco NG, Hallak JEC, et al. Cannabidiol reduces airway inflammation and fibrosis in experimental allergic asthma. Eur J Pharmacol. (2019) 843:251-9. doi: 10.1016/j.ejphar.2018.11.029
146. Hegde VL, Nagarkatti PS, Nagarkatti M. Role of myeloid-derived suppressor cells in amelioration of experimental autoimmune hepatitis following activation of TRPV1 receptors by cannabidiol. PLOS ONE. (2011) 6:e18281. doi: 10.1371/journal.pone.0018281

147. UNODC. United Nations Office on Drugs and Crime World Drug Report 2020:2-Drug Use and Health Consequences. (2020). Available online at: https://wdr.unodc.org/wdr2020/field/WDR20_Booklet_2.pdf (accessed January 20, 2021).

148. Han BH, Palamar JJ. Trends in cannabis use among older adults in the United States, 2015-2018. JAMA Intern Med. (2020) 180:60911. doi: 10.1001/jamainternmed.2019.7517

149. van Laar MW, Oomen PE, van Miltenburg CJA, Vercoulen E, Freeman TP, Hall WD. Cannabis and COVID-19: reasons for concern. Front Psychiatry. (2020) 11:601653. doi: 10.3389/fpsyt.2020.6 01653

150. Cherkasova M. Addiction in the times of pandemic. Can J Addict. (2020) 11:9. doi: 10.1097/CXA.0000000000000082

151. Bourgonje AR, Abdulle AE, Timens W, Hillebrands J, Navis GJ, Gordijn $\mathrm{SJ}$, et al. Angiotensin-converting enzyme-2 (ACE2), SARS-CoV-2 and pathophysiology of coronavirus disease 2019 (COVID-19). J Pathol. (2020) 251:228-48. doi: 10.1002/path.5471

152. Hindocha C, Freeman TP, Ferris JA, Lynskey MT, Winstock AR. No smoke without tobacco: a global overview of cannabis and tobacco routes of administration and their association with intention to quit. Front Psychiatry. (2016) 7:104. doi: 10.3389/fpsyt.2016.00104

153. Goodman S, Wadsworth E, Leos-Toro C, Hammond D, team ICPS. Prevalence and forms of cannabis use in legal vs. illegal recreational cannabis markets. Int J Drug Policy. (2020) 76:102658. doi: 10.1016/j.drugpo.2019.102658

154. Gaiha SM, Cheng J, Halpern-Felsher B. Association between youth smoking, electronic cigarette use, and COVID-19. J Adolesc Heal. (2020) 67:519523. doi: 10.1016/j.jadohealth.2020.07.002

155. Aryana A, Williams MA. Marijuana as a trigger of cardiovascular events: speculation or scientific certainty? Int J Cardiol. (2007) 118:1414. doi: 10.1016/j.ijcard.2006.08.001

156. Thomas G, Kloner RA, Rezkalla S. Adverse cardiovascular, cerebrovascular, and peripheral vascular effects of marijuana inhalation: what cardiologists need to know. Am J Cardiol. (2014) 113:187-90. doi: 10.1016/j.amjcard.2013.09.042

157. Jouanjus E, Lapeyre-Mestre M, Micallef J. Complications* FA of the RA and DMC (CEIP-AWG on C. Cannabis use: signal of increasing risk of serious cardiovascular disorders. J Am Heart Assoc. (2014) 3:e000638. doi: 10.1161/JAHA.113.000638

158. DeShazo RD, Parker SB, Williams D, Ingram JB, Elsohly $M$, Rodenmeyer $\mathrm{K}$, et al. Marijuana's effects on brain structure and function: what do we know and what should we do? A brief review and commentary. Am J Med. (2019) 132:281-5. doi: 10.1016/j.amjmed.2018. 09.006

159. National Academies of Sciences and Medicine E. The Health Effects of Cannabis and Cannabinoids: The Current State of Evidence and Recommendations for Research. Washington, DC: National Academies Press (2017).

Conflict of Interest: The authors declare that the research was conducted in the absence of any commercial or financial relationships that could be construed as a potential conflict of interest.

Copyright (c) 2021 Paland, Pechkovsky, Aswad, Hamza, Popov, Shahar and LouriaHayon. This is an open-access article distributed under the terms of the Creative Commons Attribution License (CC BY). The use, distribution or reproduction in other forums is permitted, provided the original author(s) and the copyright owner(s) are credited and that the original publication in this journal is cited, in accordance with accepted academic practice. No use, distribution or reproduction is permitted which does not comply with these terms. 